\title{
Diplomatic Dominos: South America and the Recognition of (the State of) Palestine
}

\author{
Angélica Alba Cuéllar a*, Sanford R. Silverburg b \\ a M.A. Associate Professor, Department of Political Science and International Relations, Universidad de Bogota Jorge Tadeo \\ Lozano, Bogota, Colombia. \\ b Ph.D., Professor Emeritus, Department of History and Politics, Catawba College, NC, US. E-mail: ssilver@catawba.edu. \\ *Corresponding author's email address: angelicaj.albac@utadeo.edu.co.
}

\section{A R T I C L E I N F O}

Received: 00-00-0000

Accepted: 00-00-0000

Available online: 00-00-0000

Keywords:

Diplomacy, International politics,

Middle East, Palestine,

Rights of states, South America.

JEL Classification:

\begin{abstract}
A B S T R A C T
Diplomatic recognition of the Palestinian state has made significant progress in recent years, including in Latin America. In the specific case of South America, all but one of the states have already extended some type of diplomatic recognition to Palestine. As a central issue of the Montevideo Convention on Statehood, the discussion of the meaning of diplomatic recognition in the current state system with its importance surfaces once again. The central theme of this paper is an examination of the process and explanations for South American states' provision of diplomatic recognition to Palestine, especially given by leftist governments but not necessarily as a result of a specific ideological orientation, while a single country, Colombia, part of the same cultural-geographical region, and even though attached to the same principles of the international law and decisions made by the United Nations, has not provided it.
\end{abstract}

(C) 2016 The Authors. This is an open access article under the terms of the Creative Commons Attribution License 4.0, which allows use, distribution and reproduction in any medium, provided the original work is properly cited.

DOI: http://dx.doi.org/10.18533/rss.v1i3.18

\subsection{Introduction}

On December 30, 2014, Mahmoud Abbas, President of the Palestinian Authority (PA) submitted an amended draft resolution, through the auspices of Jordan to the United Nations Security Council in an attempt to gain recognition for Palestinian statehood (UNSC, 2014). The effort failed, however, by a single vote. Formal diplomatic recognition involves the acceptance of a state or a government by another state's diplomatic or governing agency. At present, Palestine, while recognized by 136 states, 11 in South America ${ }^{1}$, remains a state in statu nascendi (Silverburg 2002, 2009). One of the basic requirements for the traditional understanding of the existence of a state is the existence of a viable and operating government (League of Nations, 1933), accepting the linked notion of territory, besides peer's recognition. This condition has been considered to be at a minimum controversial (Ashdaifat and Silverburg, 2015, Grimm, 2015).

Our goal is to first, examine the nature of South America's emergence as an important political actor at the international level, as indicated by its involvement in a complicated political issue in the Middle East. We then discuss what might be considered a contagion effect when one state after the other proceeds to diplomatically

\footnotetext{
- This article presents the preliminary findings of the research project "Colombia and the process of recognition of the Palestinian state in South America", approved by the Direction of Investigations of the University Jorge Tadeo Lozano and registered in the Group of Politics and International Relations (Colciencias registration COL0041319. Clacso Center).

${ }^{1}$ Table 1 is an indication of the extent of the continent's action and sequence of its relevant diplomacy.
} 
and thus formally recognize Palestine as a state in the international system. (Lemoine, 2012) We also focus on Colombia as the sole continental outlier in the overall process.

International and diplomatic recognition are key issues in Palestine's efforts to be acknowledged as a sovereign state, either when negotiations with Israel are nonexistent. In the process of seeking recognition of Palestine as a state, the Palestinian government undertook a diplomatic and political efforts focused on the search for bilateral recognitions. Then, it continued action at the multilateral level, especially within the United Nations, where key achievements were reached, culminated in its admission as observer non-member State and its subsequent recognition as part of the International Criminal Court. More recently, the Foreign Ministry is pursuing recognition in Europe, in an approximation, not to governments, as it did in South America, but to parliaments, and seeks to ensure that the three Latin American countries who have not expressed their recognition, Mexico, Panama and Colombia, do it soon.

In this scenario, it is essential to highlight the process of recognition of South American states, with the exception of Colombia. Although it was especially driven by leftist governments, has not necessarily occurred as a result of a specific ideological orientation, and it is more related to the concerns about international law and the engagement to the principles established by the United Nations. While there is evidence indicating a leftward ideological shift in South American governing policies, as popularized by Venezuelan president Hugo Chávez and Bolivian president Evo Morales, there is also the presence of centrist governments in Chile, Brazil, Colombia and Uruguay. These states' policies emphasize pragmatism in its diplomacy, maintaining democratic practices, and blending macroeconomic responsibility with a view toward social consciousness (Brands, 2009).

Political interest in the Middle East by Latin America is not new, nonetheless limited. But its developing relationship has been studied well by Sharif (1977) and Alba (1973). With a specific interest in the Arab-Israeli conflict, there is Sharif (1977). A more narrow focus on Palestine during the formative period when the State of Israel came into existence, the material is fairly well covered by Glick $(1958,1959)$ and Abugattas $(1982)$ and for the early Palestinian organizational efforts Barrata (1989). Our interest and focus are far narrower in geographic scope and topic. The purpose of our paper is to discuss the nature, focus, and reasoning of South American ${ }^{2}$ states with regard to recognition of the State of Palestine. This paper is to serve as an exploratory documentary account of South American states' foreign policy toward Palestine.

Table 01: State Recognition of [the State of] Palestine

\begin{tabular}{|c|c|c|c|}
\hline State action & $\begin{array}{r}\text { Position (in months) from } \\
\text { most recent act }\end{array}$ & Sequence & Date \\
\hline Argentina & 12 & 3 & December 7, 2010 \\
\hline Bolivia & 12 & 4 & December 22, 2010 \\
\hline Brazil & 12 & 2 & December 1, 2010 \\
\hline Chile & 13 & 7 & January 7, 2011 \\
\hline Colombia & $\mathrm{N} / \mathrm{A}$ & & $\mathrm{N} / \mathrm{A}$ \\
\hline Ecuador & 12 & 5 & December 24, 2010 \\
\hline Guyana & 13 & 6 & January 4, 2011 \\
\hline Paraguay & 13 & 9 & January 27, 2011 \\
\hline Peru & 13 & 8 & January 24, 2011 \\
\hline Suriname & 14 & 10 & February 14,2011 \\
\hline Uruguay & 11 & 11 & March 15, 2011 \\
\hline Venezuela & 0 & 1 & April 27, 2009 \\
\hline
\end{tabular}

Table 02: Regime type at the time of state action

\begin{tabular}{|c|c|c|c|}
\hline State & Regime Type & Date Established & $\begin{array}{r}\text { Regime Type Of Immediate } \\
\text { Predecessor }\end{array}$ \\
\hline Argentina & $\begin{array}{l}\text { Republic } \\
\text { Cristina FERNÁNDEZ DE KIRCHNER }\end{array}$ & December 10, 2007 & Nestor KIRCHNER \\
\hline B/olivia & $\begin{array}{l}\text { Republic (Social Utilitarian State) } \\
\text { Juan Evo MORALES Ayma }\end{array}$ & January 22, 2006 & $\begin{array}{r}\text { Eduardo RODRÍGUEZ VELTZÉ } \\
\text { (interino) }\end{array}$ \\
\hline Brazil & $\begin{array}{l}\text { Federal Republic } \\
\text { Dilma ROUSEFF }\end{array}$ & January 1, 2011 & Luiz Inácio Lula DA SILVA \\
\hline Chile & $\begin{array}{l}\text { Republic } \\
\text { Michelle BACHELET Jeria }\end{array}$ & March 11, 2014 & Sebastian PIÑERA \\
\hline Colombia & $\begin{array}{l}\text { Republic } \\
\text { Juan Manuel SANTOS Calderón }\end{array}$ & August 7, 2010 & Álvaro URIBE VÉLEZ \\
\hline
\end{tabular}

\footnotetext{
2 We make the clear distinction between the continent of South America and the Latin American region, which covers the Caribbean. The geographic referent Latin America can be found as early as the 1850s with a precedent appearing in 1836. Vicuña, 1973:86.
} 


\begin{tabular}{|c|c|c|c|}
\hline Ecuador & $\begin{array}{l}\text { Republic } \\
\text { Rafael CORREA Delgado }\end{array}$ & January 15, 2007 & $\begin{array}{r}\text { Alfredo PALACIO (vicepresident, } \\
\text { assumes after Lucio GUTIERREZ } \\
\text { resigns) }\end{array}$ \\
\hline Guyana & $\begin{array}{l}\text { Republic } \\
\text { Donald RAMOTAR }\end{array}$ & December 3, 2011 & Chetti JAGAN \\
\hline Paraguay & $\begin{array}{l}\text { Constitutional Republic } \\
\text { Horacio CARTES }\end{array}$ & August 15, 2013 & $\begin{array}{r}\text { Federico FRANCO (after Fernando } \\
\text { LUGO's destitution) }\end{array}$ \\
\hline Peru & $\begin{array}{l}\text { Constitutional Republic } \\
\text { Ollanta HUMALA Tasso }\end{array}$ & July 28, 2011 & Alan GARCIA \\
\hline Suriname & $\begin{array}{l}\text { Constitutional Democracy } \\
\text { Desire Delano BOUTERSE }\end{array}$ & August 12, 2010 & Ronald VENETIAAN \\
\hline Uruguay & $\begin{array}{l}\text { Constitutional Republic } \\
\text { Tabaré VAZQUEZ }\end{array}$ & March 1, 2015 & José MUJICA \\
\hline Venezuela & $\begin{array}{l}\text { Federal Republic } \\
\text { Nicolás MADURO Moros }\end{array}$ & April 19, 2013 & Hugo Rafael CHÁVEZ Frias \\
\hline
\end{tabular}

\subsection{Recognition in international law}

Under traditional international law, which means the understanding of a legal order among major western states up to and immediately after World War II (Koskenniemi, 2002) ${ }^{3}$, the ravages of a global war severely wore down those same world powers and awakened the demands of national self-determination of formerly colonial states who found it necessary to resort to violence when the metropoles refused demands for independence of former colonial dependencies. National liberation movements became widely accepted organizations that served the needs of colonial peoples' national interests. Within time, politics being the instrument of change, national liberation movements were accepted in various forms by international organizations, and finally leading to independence of those colonial dependencies. Secondly, while historically states held the position of the only form of legal personality, then international organizations and now individuals gained importance and acceptance. The nature of the global political system was soon matchedand rapidly so-by transitioning international law (Friedmann, 1964:67-71; Bederman, 2008: 172-174).

The global system revolving around states was generally oriented toward the principle of territory (Grimm, 2015: 82-92). Nevertheless, a functioning political entity necessarily rests on the need for a single government body, which Palestine has yet to establish (Ashdaifat, 2015). The expansion of independent states, particularly representing the Third World, clearly indicated a leftward shift in ideological orientation, offering an opportunity to ridicule the policies of the historic past. With regard to South America, this position takes into consideration the display of the power of North America, i.e., the United States as the epitome of imperialism. What is presented, essentially, is a paradigmatic shift which helps to explain South American foreign policies (Gardini, 2011) toward the Palestinians who are characterized as oppressed by Israeli ad/ministrative and military force over territories seized as a result of the 1967 conflict.

\subsection{Domestic considerations}

There is sufficient anecdotal evidence to lend itself to an observation that the leftward trend of a significant portion of South American states represents a continent in a position to serve as a leader of the Third World (Cameron, 2010) ${ }^{4}$. As such it becomes a spokes body for the world's "underdogs" to include the Palestinians whose national aspirations are inhibited by the Israeli occupation of former mandated territory. There certainly is also a strong inclination to broadcast a message that South American states are proud of their independence and intend to avoid American "hegemonic interferences" whenever possible, to include its policies toward the issue of Palestine. (Forero and Zacharia, 2011).

Given the relatively small percentage of Palestinians in each of the South American states, as shown in Table 3, there is not much consideration for influence emanating from the ethnic communities. Inter estingly, Latin America, a contiguous region of South America, is the host to the largest segment of the Palestinian diaspora (Baeza, 2014). Within the context of the Israeli occupation and administration of formerly Jordanian-controlled territory is the set of established demands requiring the protection of its citizens and maintaining a modicum of civil order in the Occupied Territories. The implications for Israeli relations with South American states was explosive. The Israeli military retaliatory offensive (Operation Protective Edge) in Gaza during summer 2014, which resulted in unintended but extensive collateral damage among the Palestinians, angered many in South America (Férez Gil, 2009; Boeglin, 2014; Derghougassian, 2009; RT, 2014). The horrendous coverage of the

\footnotetext{
${ }^{3}$ For a general treatment of the concept of recognition in international law see (von Glahn, 2012: 66-91).

${ }^{4}$ Table 2 indicates the governing character of the continents' states.
} 
tragic effect of the conflict led to a strongly worded joint statement at the regional trade bloc Mercosur Summit in the Caracas meeting in July 2014, condemning the Israeli actions (Infonews, 2014). From a swath of humanitarian sentiment that swept the continent, four states (Ecuador, Brazil, Peru, and Chile), recalled their ambassadors. Additionally, Chile and Brazil set aside on-going trade talks with Israel. On the far left of ideological orientations, Bolivia and Venezuela declared the Israeli military action "genocide" and Bolivia's President Evo Morales went so far as to identify Israel as a "terrorist state" (Europa, 2014). Speaking before the I ASPA (Cumbre América del Sur-Países Árabes) Summit of Heads of State and Government, in Brasilia, Brazil created a bi-regional, cooperative venture encompassing a wide range of interests and activities between the 22 states of the League of Arab States and the South American continent. (Government of Brazil, 2010; MahjarBarducci, 2011). Brazil also used its influence in 2008 to create an intergovernmental continental union of 12 South American states, the Union of South American Nations American (UNASUR), in effect raised its diplomatic status in the region and has served as a challenge to American dominance in global affairs and for our purposes here, the Middle East. (Brazil, 2008)

\subsection{Individual state's position}

\section{Argentina}

The Argentinian government, by executive order, saw fit to recognize as an independent state Palestine within 1967 borders (Government of Argentina, 2010. While purely speculative, Argentina's concern with territorial limits with the Green Line may find its implication with the country's dispute with Great Britain over control of the Malvinas/Falkland Islands. President Cristina Fernández de Kirchner sent a note to President of National Palestinian Authority, Mahmoud Abbas, manifesting this recognition, noting that it "agrees on what the parts determine in the course of negotiations" (Ministry of Foreign Relations and Cult, 2010). Argentina historically has acknowledged the right of the Palestinian people to constitute their own state and the right of Israel to live in peace, within safe and internationally recognized borders, and the recognition of Palestinian State needs to be understood in the context of the long friendship both peoples have shared. Palestinian Authority has had a diplomatic mission in Buenos Aires since 1996 while Argentina opened its embassy in Ramallah in 2008. Argentina appeared more than a little disappointed at the lack of progress in the peace process between Israel and the Palestinians. In this sense, the country's Minister of Foreign Affairs, Héctor Timmerman, indicated that Argentina's diplomatic decision was made in part because there was a "deep desire to see a definitive advance in the negotiation process leading to the establishment of a just and durable peace in the Middle East."(Berger, 2011).

\section{Bolivia}

In December 2010, Bolivian President Evo Morales (Pearce, 2011) announced his country would recognize the independence of a Palestinian state within the de facto borders that existed in 1967. This action followed Bolivia's termination of ties with Israel in 2009 after Israeli military action in Gaza (Keinon, 2010) and referred to Israel as a "terrorist state." (Tharoor, 2014). Morales stated during a press conference at Government House that "like other countries, such as Brazil recognizes (...), Bolivia holds this recognition of the Palestinian state, its independence, its sovereignty" (BoliviaSol, 2010). In November 2013, Bolivia and Palestine established diplomatic relations, and in August Bolivia joined the Committee for the Inalienable Rights of the Palestinian People and supported its incorporation as a non-member state of the United Nations. At the UN General Assembly when Bolivia announced its diplomatic action, its ambassador to the international body, Sacha Llorenti issued what was a strong statement to wit: "We support the Palestinian cause. Bolivia is a firm believer in the two-State solution, which includes an independent and sovereign Palestine based on the borders prior to those established in 1967" (Wadi, 2013). See generally Shultz (2008).

\section{Brazil}

Brazil, it should be noted has a strong immigrant interest among Muslim Arabs for some time. (Pinto, 2011) Hence, in recognition of the State of Palestine within the 1967 borders, Brazil sought a humanitarian resolution of the Arab-Israeli Conflict and noted its concern over the conditions in the Occupied Territories (Government of Brazil, 2010). The fact that Brazil, by size alone, took this action was a significant move to increase its standing politically as well as commercially linking the two regions. (Agar, 2014) The Brazilian move to a more activist position on the world stage was initiated by its president, Lula da Silva, (Bernal-Mayal, 2012; Giacagglia, 2010; Lessa, 2012; Ondetta, 2010) but has also witnessed recognition from within the region. (Gardini, 2016; Morton, 1981/1982; Wehner, 2015) On December 1, 2010, President Lula da Silva sent a letter to Mahmoud Abbas manifesting Brazil's recognition to the Palestinian State and his hope for a future pacific and safe coexistence between Israel and Palestine. This decision was a result of Abbas' petition to Brazil earlier that year and was 
coherent with Brazil's sup/port to UN resolutions against Israel's occupations of Palestinian territories. This decision was strongly criticized by the United States and Israel's governments. Toward this criticism, Brazil's foreign minister declared that "Brazil does not need US permission to conduct its foreign policy." (Merco Press, 2011). President da Silva was moved to strongly assert that there was a "growing" continental "tendency...to break out of the ghetto of U.S. diplomacy." (Gomez, 2005).

Brazil, under da Silva, has made a clear effort to expand his nation's relations with the South, plying trade relations with the Arab World as well as Africa. Indeed, Brazil has opened a number of embassies in the Arab World with da Silva as his country's first head of state to travel to 10 Arab states and Iran (Amorim, 2011: 5051). Beginning in 2005, the Arab League and the Union of South American Nations (UNASUR) have held annual summit meetings.

\section{Chile}

In early January 2011, the Chilean government, under President Sebastián Piñera, recognized a "full, free and sovereign" Palestinian State that should coexist with the State of Israel. In the statement, made by the Minister for Foreign Affairs, special emphasis was put on the urgent need to advance the process of negotiations between Palestine and Israel to reach a full and definitive agreement, in accordance with the resolutions adopted by the UN, even though there was not an explicit reference to the borders of the Palestinian state. (Government of Chile, 2011). Chilean and Palestinian peoples have had a close relation since late $19^{\text {th }}$ century, when Palestinians started to arrive at the country; today, the Palestinian community in Chile is the largest of South America borders (for a general background see (Agar, 1997, 1982; Hurtado, 2011, Olquin, 1990, Rafide, 1989; Sanfuentes, 1962).

\section{Colombia}

Colombia is the only country in South America that has shown a divergent posture to the general trend in the region and has not expressed its recognition to the Palestinian state, hence the disproportionate coverage of the state's recognition policy. One of the reasons stated by the Colombian government and its foreign minister is that recognition is contrary to the principles established by the United Nations. Maria Angela Holguín said before the vote on recognition of Palestine in the UN Security Council on September 2011: "We want a sustainable and lasting solution, above all, and that just can be a result of a bilateral dialogue between Israel and Palestine" (Semana, September 2011, Sosa, 2011).

Evidently, Colombia's close ties with Israel have had a significant effect on this position. Friendship and trade relations between the two countries are longstanding and have deepened in recent years. Colombia sees Israel as its strongest partner in the Middle East with whom it has a special closeness because of the common challenges they share regarding violence and terrorism, which has made possible closer ties of cooperation in defense and technical assistance. In addition, Israel is the main trading partner of Colombia in the region: $80 \%$ of the exchanges with the Middle East are carried out with this country (Embassy of Israel in Colombia, 2012).Despite the country's close security and commercial relationship with Israel, Colombia balanced it position regarding Palestine by raising the latter's diplomatic mission's status in the country. (TeleSur, 2011).

The current Colombian position is consistent with its foreign policy interests and its close relationship with Israel also appears as an alignment with the posture of the United States on this specific matter. An observer of American financial aid via Plan Colombia cannot help but notice that this type of assistance has a roll over effect on cementing similar foreign policy interests. (Cancillería, 2016) A quick analysis could establish that this is not an anomalous issue in a country that, in terms of its foreign policy, has historically fluctuated between respice polum and respice similia5; however, the fact is that this view is not necessarily related to the historical approach of Colombia regarding the Palestinian question, especially in terms of foreign policy and diplomacy, which contrary to what tends to be assumed, has been addressed more autonomously over several decades. Colombian foreign policy has traditionally followed the direction of neutrality, as evidenced by its position during World War I, World War II (until its vessels were attacked by Germany). In a similar vein, Colombia has participated in two peacekeeping operations, one in Egypt and the other, pursuant to a UN resolution, in Korea. (Sosa, 2011)

Contrary to claims made by Foreign Relations Minister Holguin, Colombia has a tradition of support for Palestine, as evidenced by the voting records on the issue at the United Nations. In its early stages, Colombia, by

\footnotetext{
${ }^{5}$ Respice polum, "Look to the North star," makes reference to the historic tradition of Colombian foreign policy, based around the figure of the United States as point of reference. Respice similia is referred to those times where Colombia has tried to "Look at the similar," to seek a diversification of relations in a more "horizontal" approach.
} 
the time of the partition in 1947, made by the Security Council, did not support the plan established for this purpose, considering it rushed. Then, the Colombian Ambassador Alfonso López Pumarejo proposed the postponement of the plan to study it further before making a decision with far-reaching consequences. Later, during the deliberations of the Security Council at the meeting on February 27, 1948, Pumarejo said: "...The more we think about the prospects for the Palestinian question, the more we are convinced that the resolution of November 29, 1947, was passed too hastily and that it had been possible to improve it without great difficulty and without long discussions... (Tirado et. al., 2015). This would be the foundation of the so-called "López Doctrine," which marked the beginning of a period of historical behavior of Colombia towards the Palestinian issue.

Colombia expressed early compliance to the possibility that Jerusalem and the Holy Places therein remained under international control. In a Memorandum from the Colombian Foreign Ministry on October 4, 1948, we learn that "...The city of Jerusalem and its surroundings deserve consideration as an international heritage, oblivious to any political or religious preponderance of one race over another ...But this office wants to draw the attention of other American governments on the desirability and need for this 'Special Status' to be awarded to the city of Jerusalem and its environs, including the town of Bethlehem, as 'Corpus Separatum,' that is, with a truly international character and dependent on the main form of United Nations Security Council" (Tirado et. al., 2015). However, as it was established on the principles of the "López Doctrine," Colombia took a favorable position to recognize Israel; that formally happened in February 1949.

By 1969, Colombia, for the fourth time, had a seat on the Security Council when Jordan had filed a complaint about being shelled by Israeli aircraft in February and March of that year. Colombia's position intended to address this issue towards an integral solution, that is, the withdrawal of Israeli troops from occupied territories, the recognition of Israel and end the state of belligerency. Nevertheless, Resolution 265, in which Israel was condemned, was adopted with four abstentions, including that of Colombia (Tirado et. al., 2015). This shows that the Colombian attitude was favorable to the Palestinian issue, but it didn't mean a stance of opposition to Israel. Later in the 1979 General Assembly, Colombian Ambassador expressed the Colombian government adherence to the Palestinian cause saying: "... can be said that this year, 1979, will be considered in history as the most fertile on the hard road of realization of the inalienable rights of the Palestinian people to achieve self-determination, the establishment of its homeland and the achievement of its own historical destiny. In this period, within the United Nations and outside it, the cause of the Palestinian people, beyond the interested influences of international media, begins to be accepted by many states who understand the urgent Justice of their demands ... Nor can my delegation accept the conquest of territory by the force of arms. It is a concept that goes against the diplomatic tradition of Colombia, a nation that has not won a single meter of its territory by such violence. Nor can it accepts that concept of religious history to claim sovereign rights can being invoked unilaterally..." (Tirado et. al., 2015).

During the 1983 General Assembly, Colombia maintained its support for the Palestinians' right to their own state within secure and stable borders; rejected Israel's military action in Lebanon and defended its withdrawal from Arab territories. It also opposed a possible expulsion of Israel in any international forum based on the principle of universality of international organizations, although some Israeli procedures in the occupied Arab territories against human rights were condemned (Tirado et. al., 2015). In 1989, Colombia participated for the fifth time in the Security Council. In discussions on "the situation of the occupied Arab territories," Ambassador Enrique Peñalosa presented the Colombian position: "We came today to protest before the brutal and inhumane way the Israeli occupation forces have driven the Palestinian uprising. Like the Jewish people fairly aspired to self-determination forty-two years ago, it is the aspiration of the people under occupation" (Tirado et. al., 2015).

These moments of Colombian foreign policy toward the Middle East and the Palestinian-Israeli conflict show the realization of the "Doctrine Lopez;" from the moment in which the Security Council issued the partition resolution, Colombia adopted a position that not only recognized the existence of Israel, but was also prone to openly recognize the Palestinians and their rights. This does not mean that their positions have been diametrically opposed to those of the United States, but it is true Colombia has not always been aligned with it in their postures regarding this issue.

One piece of evidence that Colombia has had a more autonomous pattern of behavior is that, as we mentioned, it has received the diplomatic representation of Palestine in their territory, which in fact has, since December 2014, the status of a "diplomatic mission," replacing the previous status of "special mission" that is temporary (El Colombiano, 2014). At this time, the Colombian Congress sent a letter to the President requesting him to analyze the possibility of recognizing the Palestinian state, which so far has had no effect. However, despite shared interests with Israel, widely considered by various political and economic sectors of the country, this 
reflects a growing institutional inclination to join their South American peers and make an explicit and official recognition of the Palestinian state that is more consistent with the Colombian traditional diplomatic position.

\section{Ecuador}

The Government of Ecuador believed that by recognizing the State of Palestine it would assist in a humanitarian venture and contribute to the resolution of the Arab-Israeli Conflict. Ecuadorian President, Rafael Correa, signed the official recognition to the free and independent Palestinian State within the 1967 borders and sent an official communication to Palestinian president. "This recognition seeks to vindicate the valid and legitimate desire of the Palestinian people to have a free and independent state" and "will be essential to achieve, through dialogue and negotiation, a peaceful coexistence between the countries of the region" of the Middle East, he added. (Government of Ecuador, 2010). As a result of Israeli Operation Protective Edge in 2014 targeting Hamas operatives in Gaza, Ecuador canceled its planned presidential visit to Israel and announced that it would establish an embassy in Ramallah. (JPost, 2014) Additionally, Ecuador strengthens its relations with Palestine by signing an Understanding Memorandum and a Reversal Note allowing for the opening of Palestinian consulates in Ecuador. (Ministerio de Relaciones Exteriores del Ecuador, 2013).

\section{Guyana}

Overall, Guyana has moved to increase its relationship with the Arab world, according to statements made at the Fourth Summit of the Arab and South American Countries (ASPA). (Guyana Chronicle, 2015). Guyana was the first member of the Caribbean Community - CARICOM in gives recognition to a free, independent and sovereign Palestinian State, based on the 1967 borders. According to the country's Foreign Minister, its actions were in concert with its support of the principle of the right of national self-determination and the solidarity with the legitimate aspirations of the Palestinian people. Additionally, the Foreign Minister employed the oft-used rationale that his country's action was directed to lend support to the Israeli-Palestinian peace process (Haaretz, 2011). Following Israeli Operation Protective Edge against Gazan-based Palestinian militants and the resulting collateral damage, Bolivian President Evo Morales issued what was called the Palestinian Manifesto, created by The Network in Defense of Humanity. This statement, demanding the removal of the Israeli presence in the Occupied Territories, was supported by Guyanan People’s Progressive Party/Civic (Singh, 2014).

\section{Paraguay}

Paraguay joined Argentina, Bolivia, Brasil, Chile, Ecuador and Perú in recognizing the State of Palestine in 2010. "By this statement, the Republic of Paraguay expressly reiterates the recognition of this state as free and independent with the borders of June 4, 1967," the Minister of Foreign Affairs said. He stated that the recognition was motivated by the diplomatic relations between both countries, established since 2005 (through Brazil and Egypt) and that the Paraguayan government reaffirms its conviction that negotiations between Israel and Palestine must be restarted in order to achieve peace and security for both nations (Government of Paraguay, 2010).

\section{Peru}

Following the action of the United Nations Special Commission on Palestine and based upon the international legal principle of national self-determination, Peru, under the domination of the APRA party, declared its recognition of the State of Palestine on January 24, 2011. (Government of Peru, 2011) But as the country's foreign minister, Jose Antonio Garcia Balunde, carefully stated, Peru held that "Palestine is recognized as a free and sovereign state" without, however, reference to the 1967 borders. (Wadi, 2013) The Minister of Foreign Affairs announced this decision, making clear that it doesn't affect Peru's relations with Israel, given that since 1940s Peru has been willing to recognize an Israeli State and a Palestinian State and has supported UN resolutions about the issue. In addition, Peru's government supports the peace process "aimed at achieving the coexistence of two states, Israel, and Palestine". The statement was made in the ASPA forum opening ceremony (Government of Peru, 2011).

\section{Suriname}

In mid-2011, Suriname joined the ranks of the non-aligned movement (NAM) in supporting the Palestinian quest for statehood within the 1967 borders and its suitable recognition. President Desi Bouterse's decision was coherent with Suriname's support to UN resolutions demanding an end to the Israeli occupation of the Palestinian territories (Chickrie, 2012). It's important to note that Suriname is an official member of the Organization of the Islamic Conference and the Islamic Development Bank, and was the second member of the 
Caribbean Community to recognize the Palestinian state, indicated by a letter from Bouterse to Palestinian Authority President Mahmoud Abbas. (Chickrie, 2012).

\section{Uruguay}

In an attempt to foster greater progress in the Arab-Israeli peace process that, in the near future, can lead to a peaceful coexistence between peoples of Palestine and Israel, within their respective states with secure borders, the Government of Uruguay decided to recognize the State of Palestine on March 2011. President José Mujica's decision was based on "the principles of international law and Resolution 181, voted at General Assembly of the UN on November 29, 1947, and Resolution 3236 of the UN General Assembly of 22 November 1974 and resolution 242 adopted by the Security Council on 22 November 1967," but no mention was made of borders in order not "to avoid interfering in an issue that would require a bilateral agreement." Uruguay and the Palestinian government had to strengthen ties in previous years; in 2010, both countries established diplomatic representations in Montevideo and Ramallah (Government of Uruguay, 2011; Merco Press, 2010). The decision was announced during the $16^{\text {th }}$ congress of FERAB (Federation of Arab Entities in Latin America) when it met in Montevideo in November 2010. (Merco Press, 2010).

\section{Venezuela}

In the perspective of a Venezuelan spokesperson, the spirit of the revolutionary efforts of heroic people of Palestine, the Government of Venezuela recognized the independent State of Palestine with Jerusalem as its capital on April 2009 (Government of Venezuela, 2011). The efforts of Venezuela to increase its friendship with the Arab World has been, in part, because of the country's heavy economic dependence on oil, which is then connected to its membership in OPEC. Under the leadership of Hugo Chavez, Venezuela made a concerted effort to use its petroleum revenue as a means to express is position amongst Third World countries and folk perceived to be oppressed by western sponsors. (Clem, 2011).This political orientation to the Arab World thus blends well with a sort of hostility toward the United States and Israel regarding Palestine, allowing for Hugo Chávez to take on the moniker, "Chávez of Arabia". (Clark, 2012).

\begin{tabular}{lrrr}
\hline & \multicolumn{2}{c}{ Table 03: Palestinian populations at the time of state action } \\
\hline Total Population & Palestinians & \% Palestinians as a part of the total \\
\hline Argentina & $43,024,374$ & Unavailable & Unavailable \\
Bolivia & $10,631,486$ & Unavailable & Unavailable \\
Brazil & $202,656,788$ & 60,000 & $3 \%$ \\
Chile & $17,363,894$ & $450,000-5000,000$ & \\
(Holston, 2005) & & & \\
Colombia & $46,245,297$ & 3,000 & Unavailable \\
Ecuador & $15,654,411$ & Unavailable & Unavailable \\
Guyana & 735,554 & Unavailable & Unavailable \\
Paraguay & $6,703,860$ & Unavailable & \\
Peru & $30,147,935$ & 10,000 & \\
(Bartet, 2011; & & & Unavailable \\
Khahat, 2010) & & Unavailable & Unavailable \\
Suriname & 573,311 & Unavailable & \\
Uruguay & & & Unavailable \\
(Arocena, & $3,332,972$ & Unavailable & \\
2009) & & & \\
Venezuela & & & \\
\hline
\end{tabular}

\subsection{Analysis}

The issue of the creation of a Palestinian state emerged prominently in the United Nations General Assembly in 1947 and has languished there and in the region since. The diplomatic and often violent conflict within the region has consistently reached global proportions as it has dragged the world's superpowers into its clutches most certainly during the Cold War and contemporaneously beyond. With the demise of Communism in the Soviet Union and the restructuring of the state as the Russian Federation, the power balance tended to shift to the United States as a unipolar hegemon. But politics cannot operate without an economic foundation. The reorganization of colonial dependencies into developing states saw the emergence of a new alliance that included a South American member. The BRICS (Brazil, Russia, India, China, and South Africa) countries (Hurrell, 2010; Kornegay, 2013) - in addition to the BASIC countries (Brazil, South Africa, India and China, the IBSA Dialogue Forum (India, Brazil, and South Africa) and the G-20 - now was an evidentiary example of a new acting balancing partner on the globe (Pape, 2005; Paul, 2005; Sotero, 2010) and the recognition of the largest 
country in South America now one with whom to be reckoned 6 . Brazil thus saw itself with a developed new status allowing it a self-perception of a power worthy of a place at the diplomatic table on world issues in addition to its regional position (Schutte, 2011). The Middle East was clearly a region to which Brazil had an interest for many reasons, fuel, culture, and trade (de Araújo, 2013). Brazil became the first South American country to achieve observer status with the League of Arab States. With all this in place and a charismatic and ambitious president, Luis Inácio Lula da Silva, there was a position favoring the establishment of an independent Palestinian state, the fervor for and has somewhat with his successor, Dilma Rousseff. (Baeza, 2014; dos Santos, 2014; Seabra, 2010; Vigevani, 2002) Brazil's move to gain acceptance in the Arab World, by sponsoring the aspirations of the Palestinians has, of course, placed itself at some distance in its relationship with Israel (Casarões and Vigevani, 2014).

Diplomatic recognition is, of course, not only a political act but also a measure of international law, the evolution of which must take into consideration contribution from South America, in turn affecting the continental states' foreign policies. The most prominent example would be the Calvo Doctrine, enunciated by the prominent Argentinian jurist Carlos Calvo in 1896 (Dugard, 2002: 3), becoming customary international law in Latin America (Dugard, 2002: 3; Obregon, 2006: 247). The lack of recognition of South America's contribution to the international rule of law was brought back to vision by the involvement in the core issue of the Arab-Israeli conflict.

Returning to the political aspects, Brazil, while the largest country on the continent, does not necessarily represent a dominant trend especially ideologically when compared with Bolivia, Ecuador, and Venezuela. There certainly is a sense of an awareness of the ascendency from the North-South situation to becoming a leader in the South-South dimension. The lingering embarrassment and resulting hostility toward the perceived imperial power to the north, can without little doubt assume to be a primary motive to pursue a policy that pokes a stick in the American eye.

The opportunity to upbraid American policy interests, in this case, the Palestinian goal of national selfdetermination, cannot be diminished. There this is also the geo-economic status of underdeveloped, perceived to be direct of the historical condition of colonialism.

\subsection{Conclusion}

Although the governments of Brazil, Argentina, Venezuela, Ecuador, and Bolivia have recognized Palestine and expressed identification with the goals of its government, other recognitions have occurred in countries under center or right wings governments, as demonstrated by the cases of Chilean President Sebastian Pinera, or Peru with Alan Garcia, who also defended the right of Palestine to exist as a state-based on the 1967 borders, defined by the United Nations. This shows the limitations of ideological argument following the examinations and attempts to associate the recognitions to the commitment of these governments to international law and the decisions of the Security Council. As it was expected, the Israeli reaction to the decisions of most South American governments has been a negative one, claiming that international recognition of Palestine as a state should occur only after a process of bi-lateral negotiation and that these recognitions try to impose a solution to the conflict from the outside. In that sense, the Colombian view is currently closer to this position and constitutes a notable exception in the subcontinent.

There ultimately is the question to which we have directed our attention, albeit indirectly, notably the position of Colombia as an outlier. Two discriminatory variables, we would argue serve to categorize the South American states' foreign policies toward the Middle East in general and Palestine in particular: South America in terms of economic development, must continue to be considered a developing region even with its productive capability, resources, and intellectual base. The area continues to harbor resentment towards its colonial past and the imposition of American influence and interests over its own national priorities. Partially in response to this set of conditions combined with the entrenched socio-economic structure which has led to a bi-modal political model, a strong leftist, trend in governance is in place. There is also, however, the possibility of reverse colonialism. One opinion in this regard was set out as: "The anticolonial response ought not to privilege the nonWestern as a matter of principle - to do so simply mirrors in the reverse logic of imperial value." (Gruffydd Jones, 2006: 225-226).

There then is Colombia that has been embroiled in a long-term insurgency and involved to some extent with the international narcotics trade. Both these conditions allowed for a difficult situation of violence. It was the effort to combat the left-wing insurgency and the "war on drugs" that brought the foreign policy interests of the United States and Colombian domestic concerns in close alignment. The strong American commitment to Israel's

${ }^{6}$ See generally Amorim (2011). For the relationship of the coalition to the Palestine Question see de Aguilar (2012). 
national security diminished any sort of support for the Palestinian cause serving, therefore, as a foundation for Colombia's distancing itself from its continental neighbors. The overwhelming support the remaining countries on the continent has given the Palestinians in their quest undoubtedly moves their effort forward. Additionally, there appears to have been a contagion effect on the sequence of diplomatic recognition of Palestine (a theory yet to be fully tested). However, since none of the countries are top tier powers, not immediately involved in the Israel-Palestine conflict, and while serving as a sounding-board, collectively have only tertiary influence.

\section{References}

Abugattas, A. J. (January 01, 1982). The perception of the Palestinian question in Latin America. Journal of Palestine Studies, 113, 117-128.

Acuña, C. H., \& Tokatlian, J. (2014). Dilemas del estado argentino: Política exterior, económica y de infraestructura en el siglo XXI.

Agar, C. L., \& Kabchi, R. (1997). El mundo árabe y América Latina. Madrid: Ediciones UNESCO.

Agar, L. (2014). El comportamiento urbano de los migrantes árabes en Chile. Revista EURE, 9(27).

Alba, V. (1973). Latin American Relations with the Middle East: The Contributing Factors. Middle East Information Series, (2): 17.

Alshdaifat, S. and Silverburg, S. R. (July, 2015). Islamic Hamas and Secular Fatah: How Does the Governing Process Work? Indonesian Journal of International and Comparative Law, 2 (3), 509-575.

Amar, P. (2014). The Middle East and Brazil: Perspectives on the new global south. Indiana University Press.

Amorim, C. (2011). Brazil and the Middle East: Reflections on Lula's South-South Cooperation. Cairo Review of Global Affairs, 1, 48-63.

Arocena, F, (2009). La contribución de los inmigrantes en Uruguay. Papeles del CEIC, Septiembre, 1-42.

Baeza, C. (2014). Can Brazil mediate the Israeli-Palestinian conflict? Assessing its strategy and capabilities (2003-2010). Lecture presented at FLACSO/ISA Congress, Buenos Aires.

Baeza, C. (January 01, 2014). Palestinians in Latin America: Between assimilation and long-distance nationalism. Journal of Palestine Studies, 43, 2, 59-72.

Barrata, R. (1989). The PLO in Latin America. In: A. Norton and M. Greenberg (Ed). The International Relations of the Palestine Liberation Organization, Carbondale: Southern Illinois University Press, 166-195.

Barroso de Aguiar, L. (2011, December). BRICS Policy Center. Retrieved January 16, 2016, from http://bricspolicycenter.org/homolog/Job/Interna/2409.

Bartet, L. (2005). Memorias de cedro y olivo: La inmigración árabe al Perú: (1885-1985). Lima: Fondo Editorial del Congreso del Perú.

Bartet, L., Kahhat, F., \& Abugattas, D. (2010). La huella árabe en el Perū. Lima: Fondo Editorial del Congreso del Perú.

B/ederman, D. J. (2008). Globalization and international law. New York: Palgrave Macmillan. http://dx.doi.org/10.1057/9780230612891

Berger, R. (2011, January 28). Latin America and Palestine: Watershed or Worthless? Retrieved October 22, 2015, from http://www.americasquarterly.org/node/2213/

Bernal-Meza, R. (December 01, 2010). International thought in the Lula era. Revista Brasileira de Política Internacional, 53, 193-213.

Boeglin, N. (2014). Reacciones en América Latina a la operación 'Margen Protector' del ejército israelí en la franja de Gaza. Reportes del Centro de Estudios de Media Oriente y África del Norte (CEMOAN), (15): 2-9. Retrieved February 16, 2016, from http://www.cemoan.org/reportegaza.html.

Bourne, R., \& University of California Press. (2008). Lula of Brazil: The story so far. Berkeley: University of California Press. http://dx.doi.org/10.1590/S0103-97332008000200002

Brands, H. (2009). Dealing with Political Ferment in Latin America: The Populist Revival, the Emergence of the Center, and Implications For U.S. Policy. Carlisle, PA: Strategic Studies Institute, U.S. Army War College.

Cameron, M. A. \& Hershberg, E. (2010). Latin America's Left Turn: Politics, Policies, and Trajectory of Change. Boulder, CO: Lynne Rienner.

Casarões, G. \& Vigevani, T.. (2014). 0 lugar de Israel e da Palestina na política externa brasileira: antissemitismo, voto majoritário ou promotor de paz? História (São Paulo), 33(2), 150-188.

Chickrie, R. (2011, February 2). Suriname recognizes Palestinian state. Caribbean Muslims. Retrieved November 22, 2015, from http://www.caribbeanmuslims.com/blogs/120/Suriname-recognizes-Palestinianstate.html.

Chickrie, R. (2012, November 28). Guyana and Suriname to support Palestine statehood at UN. Curacao Chronicle. Retrieved March 15, 2016, from http://curacaochronicle.com/region/guyana-and-suriname-tosupport-palestine-statehood-at-un/ 
Clark, M. (2009, May 20). Arabs' new favorite leader: Hugo Chávez!?!. The Christian Science Monitor. Retrieved November 22, 2015, from http://www.csmonitor.com/World/Global-News/2009/0520/arabs-newfavorite-leader-hugo-chavez

Clem, R. S., \& Maingot, A. P. (2011). Venezuela's petro-diplomacy: Hugo Chávez's foreign policy. Gainesville: University Press of Florida. http://dx.doi.org/10.5744/florida/9780813035307.001.0001

Col/ombia Upgrades Palestine's Diplomatic Status (March 2, 2011). TeleSur. Retrieved February 16, 2016, from http://www.telesurtv.net/english/news/Colombia-upgrades-palestines-diplomatic-status.

De Araújo, R. (2013, August 1). Brazil: Is There A Clear Foreign Policy for the Middle East and Africa? Orientalia. Retrieved January 18, 2016, from https://orientalia.hypotheses.org/123.

Derghougassian, K. (2009). La cercanía de un conflicto lejano: la repercusión de la guerra de Israel en Gaza en América Latina. Foro Europa-América Latina/Fundación para las Relaciones Internacionales y el Diálogo Exterior (FRIDE).

Dugard, J. (2002, March 7). Third report on diplomatic protection (Rep. No. A/CN.4/523 and Add.1). International Law Commission. Retrieved January 18, 2016, from http://legal.un.org/ilc/documentation/english/a_cn4_523.pdf

Ecuador to open embassy in 'Palestine', president cancels visit to Israel. (2014, August 6). Jerusalem Post. Retrieved February 16, 2016, from http://www.jpost.com/Operation-Protective-Edge/EcuadorianPresident-cancels-trip-to-Israel-370310.

El/ Mercosur condenó la violencia en Gaza (2014, July 29). Infonews. Retrieved November 22, 2015, from http://www.infonews.com/nota/155589/el-mercosur-condeno-la-violencia-en-gaza.

Embassy of Israel in Colombia (June 19, 2012). Relaciones Bilaterales. Retrieved Novembre 23, 2015, from http://embassies.gov.il/bogota/Relations/Pages/Relaciones-Israel-Colombia.aspx.

Evo Morales considera a Israel un "Estado terrorista" y cancela el acuerdo de visados (2014, July 30). Europa Press. Retrieved January 16, 2016, from http://www.europapress.es/internacional/noticia-evo-moralesconsidera-israel-estado-terrorista-cancela-acuerdo-visados-20140730223045.html.

Férez, G. M. (2009). El conflicto en Gaza e Israel 2008-2009: Una visión desde América Latina. México: Senado de la República.

Forero, U., \& Zacharia, J. (2011, February 18). Palestinians seek global recognition through South America. The Washington Post. Retrieved November 20, 2015, from http://www.washingtonpost.com/wpdyn/content/article/2011/02/16/AR2011021602232.html.

Gardini, G. L., \& Almeida, M. H. T. (2016). Foreign policy responses to the rise of Brazil: Balancing power in emerging states. New York: Palgrave Macmillan.

Gardini, G. L., \& Lambert, P. (2011). Latin American foreign policies: Between ideology and pragmatism. New York: Palgrave Macmillan. http://dx.doi.org/10.1057/9780230118270

Giaccaglia, C. (January 01, 2010). La influencia de los actores domésticos en la política exterior brasileña durante el gobierno de Lula da Silva. Confines De Relaciones Internacionales Y Ciencia Política (méxico), 6, 12, 95121.

Giaccaglia, C., \& Lechini, G. (December 01, 2010). El ascenso de Brasil en tiempos de Lula ¿Líder regional o jugador global? Problemas Del Desarrollo, 41, 163, 53-73.

Gobierno Bolivariano de Venezuela (November 27, 2009). Gobierno Bolivariano ratifica apoyo a la causa palestina. $\quad$ Retrieved November $\quad 11, \quad 2015, \quad$ from http://www.mre.gov.ve/index.php?option=com_content\&view=article\&id=2988:gobierno-bolivarianoratifica-apoyo-a-la-causa-palestina\&catid $=2$ :actualidad\&itemid $=325$

Gómez, E. (2005, May 17). World Views: U.S. snubbed at first South American-Arab summit. SFGate. Retrieved February 18, 2016, from http://www.sfgate.com/politics/article/WORLD-VIEWS-U-S-snubbed-at-firstSouth-2670152.php.

Grimm, D. (2015). Sovereignty: The origin and future of a political and legal concept. Columbia Studies in Political Thought / Political History. New York: Columbia University Press.

Gruffydd, J. B. (2006). Decolonizing international relations. Lanham, Md: Rowman \& Littlefield.

Guyana Becomes 7th South American State to Recognize Palestinian independence. (2011, January 14). Haaretz. Retrieved February 18, 2016, from http://www.haaretz.com/israel-news/guyana-becomes-7th-southamerican-state-to-recognize-palestinian-independence-1.336944.

Guyana seeks deeper ties with Arab States (2015, November 12). Guyana Chronicle. Retrieved January 16, 2016 , from http://guyanachronicle.com/guyana-seeks-deeper-ties-with-arab-states/.

Holston, M. (2005, December). Orgullosos palestinos de Chile. Américas, Vol. 57 Issue 6, p 5.

Hurrell, A., (2010). Brazil and the New Global Order. Current History, 179 (724): 60-66.

Hurtado, A. M. (Dir.) (2011). Palestine in the South [Motion picture]. Chile: Antipoder.

Keinon, H. (2010, December 17). Bolivia Latest State to Recognize 'State of Palestine'. Jerusalem Post. Retrieved February 18, 2016, from http://jpost.com/international/Bolivia-latest-state-to-recognize-State-ofPalestine. 
Khatib, D., (2014, August 9). Palestine Present More Than Ever in Latin American Politics. Aljazeera. Retrieved January 17, 2016, from http://www.aljazeera.com/indepth/opinion/2014/08/palestineresentmorethaneverlatinamericanpolitics-201487847495.

Kornegay, F. A., \& Bohler-Müller, N. (2013). Laying the BRICS of a new global order: From Yekaterinburg 2009 to eThekwini 2013. Oxford: African Books Collective.

Koskenniemi, M. (2002). The gentle civilizer of nations: The rise and fall of international law. 1870-1960. Cambridge, UK: Cambridge University Press.

La legación de Palestina en Colombia alcanza estatus de misión diplomática (December 6, 2014). El Colombiano. Retrieved February 16, 2016, from http://www.elcolombiano.com/la-legacion-de-palestina-en-colombiaalcanza-estatus-de-mission-diplomatica-DB838115.

Latinoamérica: Avanza reconocimiento al estado palestino (December 25, 2010). Bolivia Sol. Retrieved February 16, 2016, from https://boliviasol.wordpress.com/2010/12/25/latinoamerica-avanza-reconocimiento-alestado-palestino/.

League of Nations Treaty Series (December 26, 1933). The Montevideo Convention on the Rights and Duties of States. Vol. 165: 20-43.

Lemoine, M. \& Waterhouse, R. (2012). Latin America Embraces Palestine. In Kristianasen, W. (Ed.) The Best of Le Monde Politique 2012. New York: Pluto Press, pp. 72-74.

Lessa, A. C. (2012). Brazil's strategic partnership: an assessment of the Lula era (2003-2010). Revista Brasileira de Politica internacional, 53: 115-131.

Mahjar-Barducci, A. (February 15, 2011). Arab, South American Region to Create a New Geopolitical Space of Global Importance. Gatestone Institute. Retrieved February 16, 2016, from http://gatestoneinstitute.org/1893/arab-south-american-region.

Margheritis, A. (2010). Argentina's foreign policy: Domestic politics and democracy promotion in the Americas. Boulder: FirstForumPress.

Ministério das Relaçõnes Exteriores, Governo do Brasil (2010). History of ASPA. Retrieved February 16, 2016, from http://www2.mre.gov.br/aspa/history.html.

Ministério das Relaçõnes Exteriores, Governo do Brasil (2010). The Doha Declaration. Retrieved February 16, 2016, from http://www2.mre.gov.br/aspa/doha_declaration.doc.http://www2.mre.gov.br/aspa/doha_declaration.doc

Ministério das Relaçõnes Exteriores, Governo do Brasil (2010). What is ASPA? Retrieved February 16, 2016, from http://www2.mre.gov.br/aspa/waspa.html.

Ministério das Relaçõnes Exteriores, Governo do Brasil (Mayo 23, 2008). Documentos da Nações SulAmericanas. $\quad$ Retrieved February 16, 2016, from http://www.itamaraty.gov.br/index.php?option=com_content\&view=article\&id=13221:documentos-dauniao-de-nacoes-sul-americanas\&catid=2\&lang=pt-BR\&Itemid $=478$.

Ministerio de Relaciones Exteriores de Argentina (2010) Información para la prensa No. 559/10. Retrieved February 15, 2016, from http://www.cancilleria.gob.ar.

Ministerio de Relaciones Exteriores de Argentina (2010). La República argentina ha reconocido a palestina como estado libre e independiente. Retrieved February 16, 2016, from https://www.mrecic.gov.ar/node/34304.

Ministerio de Relaciones Exteriores de Chile (January 7, 2011). Declaración del Gobierno de Chile sobre el reconocimiento del Estado de Palestina. Retrieved February 16, 2016, from http://www.minrel.gov.cl/prontus_minrel/site/artic/20110107/pags/20110107165601.php.

Ministerio de Relaciones Exteriores de Paraguay (January 28, 2011). Reconocimiento del Estado de Palestina. Retrieved January 22, 2016, from http://www.mre.gov.py/v2/Contenido/22/normativa.

Ministerio de Relaciones Exteriores de Perú (January 24, 2011). Perú reconoce al Estado Palestino. Comunicado de Prensa No, 001-11.

Ministerio de Relaciones Exteriores de Uruguay (2011, March 15). La República Oriental de Uruguay reconoció oficialmente al Estado Palestino. Retrieved November 20, 2015, from http://www.mrree.gub.uy/frontend/page?1,main,ampliacion-actualidad,0,en,0,PAG;CONC;128;2;D;larepublica-oriental-de-uruguay-reconocio-oficialmente-al-estado-palestino;2;PAG;

Ministerio de Relaciones Exteriores de Uruguay (March 11, 2011). El Gobierno Uruguay reconoció al Estado Palestino. Comunicado de Prensa No. 28/11. Retrieved January 22, 2016, from http://www.mrree.gub.uy/frontend/page?1,inicio,ampliacion-actualidad,0,es,0,PAG;CONC;1662;4;D;elgobierno-uruguayo-reconocio-al-estado-palestino;1;PAG.

Ministerio de Relaciones Exteriores y Movilidad Humana, Gobierno de Ecuador (December 24, 2010). Ecuador reconoce al Estado Palestina. Boletín de Prensa No. 992.

Ministerio de Relaciones Exteriores, Gobierno de Ecuador y Movilidad Humana (2013). Ecuador and Palestine Strengthen Bilateral Relations. Retrieved February 15, 2016, from http://www.cancilleria.gob.ec/.

Morton, F.W.O. (1981). "Brazil's Emergence on the World Stage," International Journal, 37 (1) (Winter): 13-41.

Obregon, C. (2006). Consciousness and International Law in Nineteenth-century Latin America. In Orford, A. (Ed.). International law and its others. Cambridge: Cambridge University Press.

Olguín, T. M., \& Peña, G. P. (1990). La inmigración árabe en Chile. Santiago, Chile: Ediciones Instituto Chileno Arabe de Cultura. 
Ondetti, G., \& Rhodes, S. (2010). Courting the South: Lula's trade diplomacy. Serie Documentos de Trabajo, Universidad del CEMA: Área: Ciencia Política y Relaciones Internacionales 430. Universidad del CEMA, Buenos Aires.

Pape, R. (June 01, 2006). Soft balancing against the United States. Peace Research Abstracts Journal, 43, 3. doi: http://dx.doi.org/10.1162/0162288054894607.

Paredes, C. (September 19, 2011). El rol de Colombia en el reconocimiento de Palestina. Semana. Retrieved February 16, 2016, from http://www.semana.com/nacion/articulo/el-rol-colombia-reconocimientopalestina/246683-3.

Paul, T. V. (July 01, 2005). Soft Balancing in the Age of U.S. Primacy. International Security, 30, 1, 46-71. doi: http://dx.doi.org/10.1162/0162288054894652

Pearce, A.J. (2011). Evo Morales and the Movimiento al Socialismo in Bolivia: The First Term in context, 20062010. London: Institute for the Study of the Americas, University of London.

Perazza, F. (2007-2008). Uruguay y el conflicto en Medio Oriente. Revista Mexicana de Política Exterior, (82): 165-204.

Pinto, P. G. (October 05, 2011). Arab Ethnicity and Diasporic Islam: A Comparative Approach to Processes of Identity Formation and Religious Codification in the Muslim Communities in Brazil. Comparative Studies of South Asia, Africa and the Middle East, 31 (2), 312-330.

Rafide, M. (1989). Escritores chilenos de origen árabe: Ensayo y antología. Santiago, Chile: Instituto ChilenoArabe de Cultura.

Sanfuentes, A. (1962). La influencia de los árabes en el desarrollo económico de Chile. Santiago de Chile: Facultad de Ciencias Económicas de la Universidad de Chile.

Santos, N. B. (2014). A política externa do governo Lula com relação ao conflito Israel-Palestina. História (São Paulo) História, 33(2), 189-216. http://dx.doi.org/10.1590/1980-436920140002000010

Schutte, G. R., (July 11, 2011). The Pillars of Brazil's International Activism. Policy Network. Retrieved February 16, 2016, from http://www.policy-network.net/pnodetail.aspx? ID =4030\&title $=$ The+pillars + of +Brazils+international+activism.

Seabra, P., (December, 2010). Brazil and the Recognition of the Palestinian State: More Than Words? IPRIS Viewpoints. Portuguese Institute for International Relations and Security. Retrieved February 16, 2016, from www.ipris.org/php/download.php?fid=330.

Sharif, R. (October 01, 1977). Latin America and the Arab-Israeli Conflict. Journal of Palestine Studies, 7, 1, 98122. doi: http://dx.doi.org/10.2307/2536530.

Shultz, J., \& Draper, M. (2008). Dignity and defiance: Stories from Bolivia's challenge to globalization. Berkeley, CA: University of California Press.

Silverburg, S. R. (2002). Diplomatic Recognition of States in statu nascendi, in Sanford R. Silverburg, (Ed). Palestine and International Law: Essays on Politics and Economics, Jefferson, N.C: McFarland \& Co.

Singh, R. (August 11, 2014). PPP Will Sign 'Palestine Manifesto' - Rohee. Guyana Chronicle. Retrieved February 16, 2016, from http://guyanachronicle.com/ppp-will-sign-palestine-manifesto-rohee/.

Sosa, S. (October 13, 2011). Colombia's Stance on Palestine. Colombia Reports. Retrieved February 16, 2016 , from http://colombiareports.com/colombias-stance-on-palestine/.

Sotero, P. (December 01, 2010). Brazil's Rising Ambition in a Shifting Global Balance of Power. Politics, 30,71 81. doi: http://dx.doi.org/10.1111/j.1467-9256.2010.01394.x.

'Stop the Genocide!' S. American Leaders Condemn Israeli Operation in Gaza (July 20, 2014). RT. Retrieved February 16, 2016, from http://rt.com.news/174144-south-america-gaza-genocide/.

Tharoor, I. (July 31, 2014). Latin America's Support for Palestinians and the Echoes of the Cold War. The Washington Post. Retrieved February 16, 2016, from http://www.washintonpost.com/news/worldviews/wp2014/07/31/latin-americas-support-forpalestinians-and-the-echoes-of-the-cold-war.

Tirado M. A., Holguín H. C. (2015). Colombia en la ONU 1945-1995. Capítulo III: Algunas Posiciones de Colombia. Colombia ante las Naciones Unidas. Mision permanente de Colombia ante las Naciones Unidas. Retrieved February 16, 2016, from http://www.colombiaun.org/Historia/Participacion\%2019451995/Articulos/capitulo_III.html.

United Nations, Security Council (December 30, 2014). S.C. Res. S/2014/916.

Uruguay Formalizes Relations With Palestine and Plans Representation in Ramallah (November 15, 2010). Merco Press. Retrieved February 16, 2016, from http://en.mercopress.com/2010/11/15/uruguayformalizes-relations-with-palestine-and-plans-representation-in-ramallah.

US Condemns South American/Arab Leaders Summits, Say Wikileaks Cables 2011 (February 7, 2011). Merco Press. Retrieved February 16, 2016, from http://en.mercopress.com/2011/02/07/us-condemns-southamerican-arab-leaders-summits-say-wikileaks-cables.

Vervaele, J. (2005). Mercosur and Regional Integration in South America. International Comparative Law Quarterly, 54, 387-410. http://dx.doi.org/10.1093/iclq/lei007 
Vicu-a, O. (1973). Contemporary International Law in the Economic Integration of Latin America. In Rideau, J. Les aspects juridiques de l'integration economique. Leiden: Sijthoff.

Vigevani, T. et al. (2002). Conflito Palestina-Israel: anacronismo, contemporaneidade e o papel do Brasil in Dupas, G., \& Vigevani, T. Israel-Palestina: A construção da paz vista de uma perspectiva global. São Paulo: Editora Unesp, 19-46.

Von Glahn, G. \& Taulbee, J. L. (2012). Law among Nations: An Introduction to Public International Law. 10 th ed. New York: Routledge.

Wadi, R. (2013, November 28). Similarities between Palestine and Latin America invoked in Bolivian message of solidarity. Middle East Monitor. Retrieved October 20, 2015, from https://www.middleeastmonitor.com/blogs/politics/8554-similarities-between-palestine-and-latinamerica-invoked-in-bolivian-message-of-solidarity

Wadi, R. (December 2, 2013). President of the Palestinian Federation of Peru on the Palestinian Community in Peru, Internationalism and Democratic Unity. Middle East Monitor. Retrieved February 16, 2016, from http://www.middleeastmonitor.com/resources/interviews/8606-president-of-the-palestinian-federationof-peru-on-the-palestinian-community-in-peru.

Wehner, L. E. (October 01, 2015). Role Expectations As Foreign Policy: South American Secondary Powers' Expectations of Brazil As A Regional Power. Foreign Policy Analysis, 11, 4, 435-455. 